\title{
Experimental and field approach to the hydraulics of nature-like pool-type fish migration facilities
}

\author{
R.W. Wang ${ }^{(1)}$, A. Hartlieb(2) \\ Received July 17, 2010 / Reçu le 17 juillet 2010 \\ Revised December 23, 2010 / Révisé le 23 décembre 2010 \\ Accepted January 3, 2011 / Accepté le 3 janvier 2011
}

Key-words: nature-like

ramp,

fish passes, turbulent kinetic energy

\section{ABSTRACT}

Nature-like fish migration facilities have gradually become a common type to ensure longitudinal connectivity of fish movements in running waters. This article presents verification on hydraulic and geometric parameters of nature-like pool-type fish passes via experimental and field investigations. The experiment verified that the maximum streamwise velocity near a slot ranged from 0.8-1.0 time of the theoretical maximum velocity. Large vertical recirculations presented below sills, moved downstream with the increase in discharge, and were likely to vanish or to change the rotation direction with high flow conditions. High turbulent kinetic energy distributed immediately downstream from boulder sills instead of along the water jet. Fieldwork was conducted at a full-width ramp in Kolbermoor and a partial-width ramp in Leitner in Bavaria under low, mean and high flow conditions to investigate the flow and geometry characteristics in real constructions and under various hydrologic conditions. The results for velocity show confidence in the method to obtain the maximum value around a slot by measuring at one depth only. Instead of flow velocity, water depth played a more critical role in the performance of a nature-like fishway, in particular under low flow conditions, and so did the arrangement of boulders along a sill. A detailed hydraulic/geometric investigation, together with biological monitoring, should be conducted to identify appropriate criteria on assessment of fish free passage at nature-like fish migration facilities.

\section{RÉSUMÉ}

Approche expérimentale et de terrain de l'hydraulique des passes

à poissons « naturelles »

Mots-clés:
passe
"naturelle ",
passe à
poissons,
énergie
cinétique
turbulente

Les passes "naturelles" sont devenues progressivement fréquentes pour améliorer la connectivité longitudinale des déplacements des poissons dans les eaux courantes. Cet article présente une vérification des paramètres hydrauliques et géométriques des passes « naturelles " par des études expérimentales et de terrain. L'expérience a vérifié que la vitesse maximale du courant près des fentes est comprise entre 0,8 et 1 fois la vitesse théorique maximale. De larges recirculations verticales présentes en dessous des seuils se déplacent vers l'aval lors d'une augmentation du débit et disparaissent probablement ou changent de sens de rotation aux conditions de fort débit. Une forte énergie cinétique

(1) Former Ph.D. Student, Institute of Hydraulic and Water Resources Engineering, Technische Universität München, Germany, rueywen.wang@gmail.com

(2) Managing Engineer, Laboratory of Hydraulic and Water Resources Engineering, Technische Universität München, Versuchsanstalt Obernach, 82432 Walchensee, Germany, a.hartlieb@bv.tum.de 


\begin{abstract}
turbulente est présente immédiatement en aval des seuils en blocs. Le travail de terrain a été mené sur une passe occupant toute la largeur du cours d'eau à Kolbermoor et d'une passe sur une partie de la largeur du cours d'eau à Leitner en Bavière, dans des conditions de bas, moyen et haut débits pour étudier les caractéristiques du flux dans des conditions réelles et des débits différents. Les résultats sur la vitesse montrent qu'on peut obtenir une bonne estimation de la valeur maximale par mesure à une seule profondeur. Plutôt que la vitesse du courant, l'épaisseur de la couche d'eau joue un rôle plus critique dans les performances d'une passe « naturelle », en particulier en bas débit. Une étude hydraulique/géométrique détaillée, accompagnée d'un suivi biologique, doit être conduite pour déterminer les bons critères d'évaluation du passage libre pour les poissons dans les passes «naturelles ».
\end{abstract}

\title{
INTRODUCTION
}

During the 19th and 20th centuries, river regulations were introduced for various purposes; therefore, weirs, dams and artificial channels were built for the benefit of humans. However, such constructions pose obstacles and interrupt the longitudinal connectivity of a river, and together with other factors such as water pollution, lead to a decrease in the population of certain species of fish, sometimes even bringing them close to extinction (FAO and DVWK, 2002).

Fish passes are structures that facilitate upstream migration of fish over obstacles; the conventional types include Denil, pool-type and vertical-slot fish passes, etc. In the past two decades, nature-like fish passes (NLF) have become a very common type of fish migration facility, in particular in Germany (Gebler, 1991; DVWK, 1996; Heimerl et al., 2005) and in Austria (Schmutz et al., 1998; Stephan et al., 2007). These fish passes resemble natural river rapids or brooks, and are supposed to be less species-selective, i.e. passable for various fish species, as well as for both adult and small/juvenile fish (DVWK, 1996; Katopodis et al., 2001; Larinier et al., 2002).

Classification of NLFs is based on structures, with the arrangement of boulders (DVWK, 1996) and the ways of dissipating energy (Larinier et al., 2006); they include embedded-boulder constructions, ramps with perturbation boulders, and pool-type ramps (also known as ramps with boulder sills or cascaded ramps). Another classification of NLFs is based on their locations relative to barrages (DVWK, 1996; Larinier et al., 2006); they are bottom ramps and bypass channels. Bottom ramps form a two-dimensional rough bottom throughout the entire river width (thereafter referred to as a full-width ramp), and therefore, discharge passing through a ramp equals the discharge in a river. Sometimes bottom ramps are applied to replace a portion of an obstacle across running waters (thereafter referred to as partial-width ramp) because such an obstacle is still in service or available river discharge is limited. A natural bypass channel is an artificial river built in the bank to mimic a natural watercourse and to link the forebay and tailbay of an obstacle without structural modification of the obstacle itself (DVWK, 1996; Larinier et al., 2002). Figure 1 shows examples of a full-width ramp and a partial-width ramp.

Conventional fishways have been studied for many years; the same is not true for nature-like fishways (Katopodis et al., 2001). Although design principles in geometry and many examples of implementation of such NLFs have been presented (Gebler, 1991; DVWK, 1996; Larinier et al., 2002, 2006), dimensioning of NLFs, e.g. with perturbation boulders (Larinier et al., 2006; Heimerl et al., 2008) or boulder sills (Larinier et al., 2006), has just been proposed in the past few years, and the verification of NLFs' performance has been rarely reported. Additionally, a technical fishway is generally built as a design since concrete is the main material of the structure and the construction accuracy can be controlled. However, most of the NLFs built have geometry and hydraulics with greater variation from their blueprint. The reasons could be (1) the river bottom after being graded is not as smooth as a concrete slope; (2) boulder 


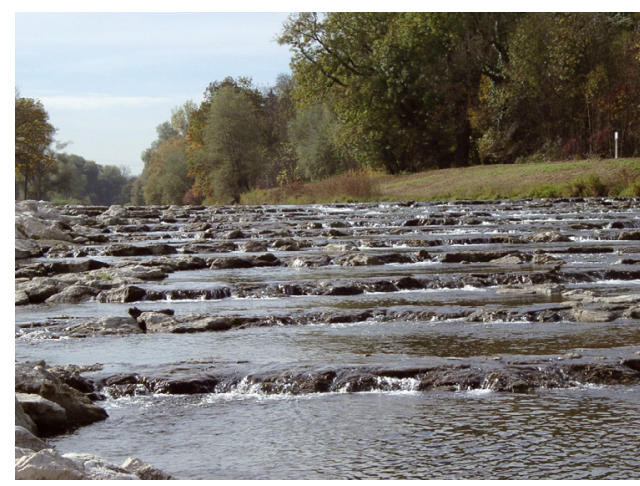

(a)

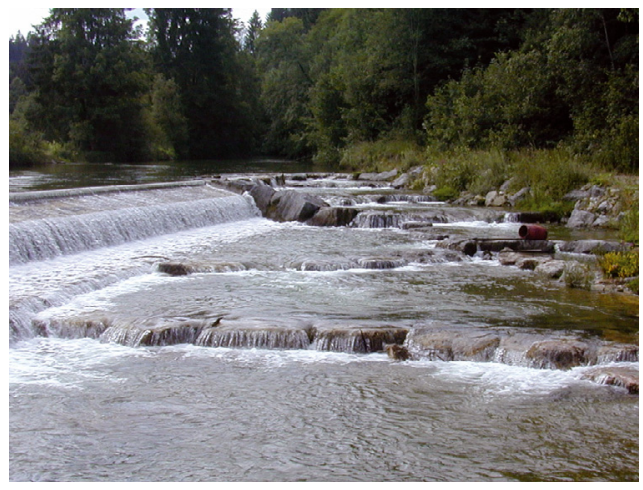

(b)

\section{Figure 1}

Nature-like fish migration facilities: (a) full-width pool-type bottom ramp (ramp with boulder sills or cascaded construction) in Kolbermoor, upper ramp; (b) partial-width pool-type bottom ramp in Leitner.

\footnotetext{
Figure 1

Passes à poissons « naturelles » : (a) sur toute la largeur du cours d'eau avec des seuils en blocs et des petites chutes à Kolbermoor; (b) sur une portion de largeur à Leitner.
}

dimensions and weights for sills are different from the original design, or (3) boulder allocation by grabber limits the geometrical accuracy of sills.

The objectives of this study are to verify whether the required hydraulics and geometry in pooltype NLFs are respected after they are implemented, and to suggest a feasible procedure to assess hydraulics and passage geometry of constructed NLFs. A physical model was built at the Laboratory of Hydraulic and Water Resources Engineering in Obernach (Germany) for the experimental study. Particular attention was given in the model test to resembling actual NLF configurations - using stones to assimilate boulders, instead of simplified forms, e.g. regular shaped blocks made of concrete, plastic or other artificial materials. We also selected two ramps, one full-width pool-type ramp in Kolbermoor and one partial-width pool-type ramp in Leitner, located in the river system of Mangfall in Bavaria, to conduct the field investigation during 2006 and 2007.

We have to emphasize that construction of fish passes, no matter whether they are NLFs or technical types, is highly adjusted to adapt to local conditions. The required hydraulic and geometric conditions for NLFs and the fish species to be passed referred to in this article are based on the German literature to introduce the German experience in design, verification of NLFs, and philosophy of fish pass effectiveness assessment.

\section{MATERIALS AND METHODS}

\section{> EXPERIMENTAL ARRANGEMENTS AND INSTRUMENTS IN THE MODEL TEST}

This experiment was conducted in a rectangular flume (length: $12 \mathrm{~m}$; width: $50 \mathrm{~cm}$ ), as shown in Figure 2, along with the coordinate system $(X, Y, Z)$. Fourteen boulder sills were used as cross-walls to separate the pools. The flume bottom was covered by gravels with diameter of $4-8 \mathrm{~mm}$. Boulder sills are numbered as $\mathrm{S} 1$ to $\mathrm{S} 14$ from upstream to downstream. The length $(L)$ and width $(B)$ of each pool were $40 \mathrm{~cm}$ and $50 \mathrm{~cm}$, respectively, with the ratio of $B / L=1.25$. The boulder sills involved two different stone sizes: stones approximately $10 \mathrm{~cm}$ in height brought the sills to the desired height, and smaller stones of approximately $3.5 \mathrm{~cm}$ provided an opening to ensure free passage under low discharge conditions (Figure 2e). The openings were located on alternative sides at sills to prevent a strong concentrated flow on one side. This model was tested for slope, $S=1: 30(3.33 \%)$, and three discharges, $Q_{m}$, 

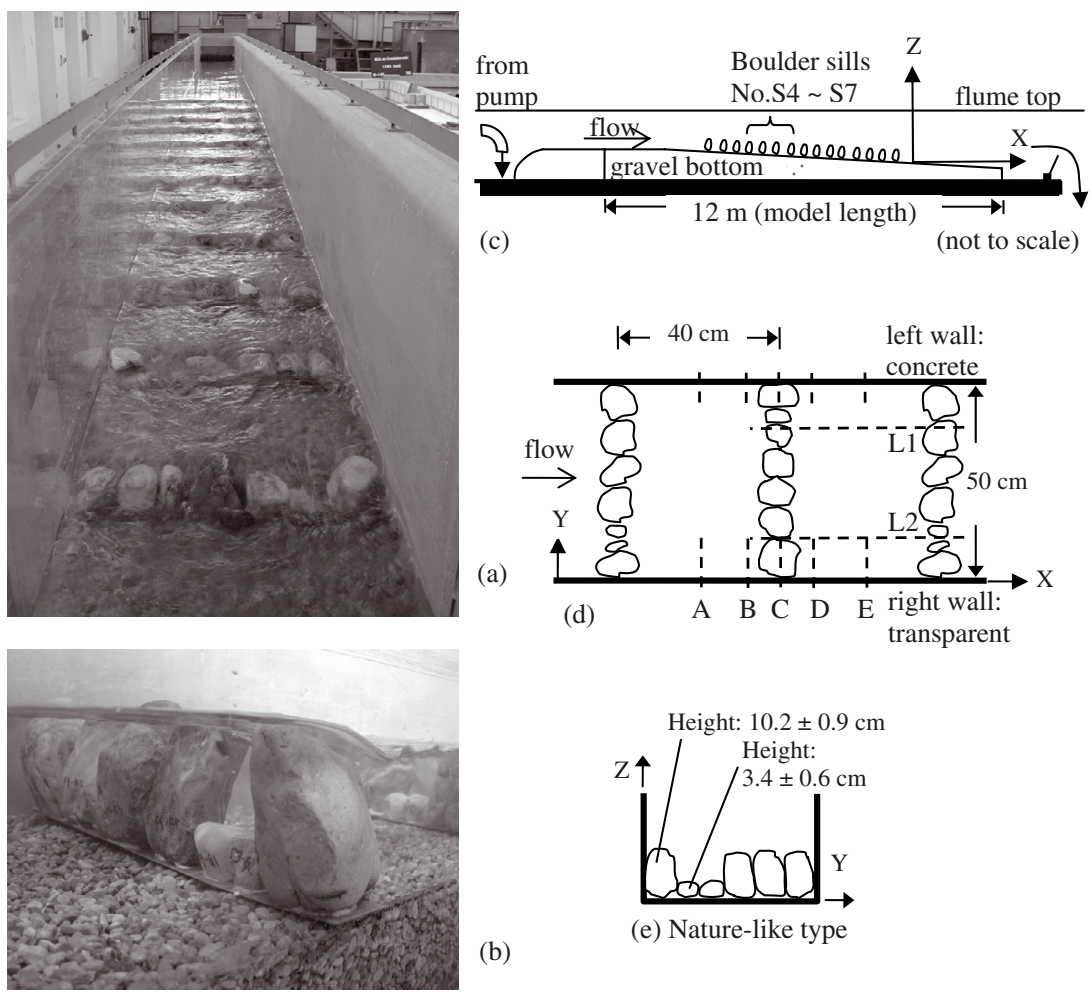

(a)

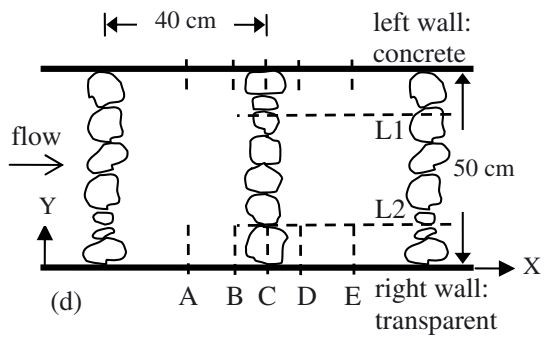

(b)

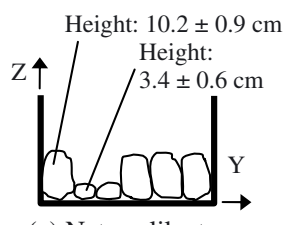

(e) Nature-like type

\section{Figure 2}

Experimental flume of the pool-type NLF with boulder sills: (a) view from downstream; (b) boulder sill; (c) side view; (d) detail of boulder sills and measured planes - A E: cross-sections; L1 and L2: longitudinal sections, plan view; (e) detail of boulder sills, front view.

\section{Figure 2}

Chenal expérimental de passe avec des seuils en galets : (a) vue depuis l'aval ; (b) seuil en galets ; (c) vue latérale; (d) détail de seuil en galets et points de mesure; (e) détail d'un seuil en galets en vue frontale.

of $6.71 \mathrm{~L} \cdot \mathrm{s}^{-1}, 8.94 \mathrm{~L} \cdot \mathrm{s}^{-1}$ and $11.18 \mathrm{~L} \cdot \mathrm{s}^{-1}$, which correspond to the specific discharges in the prototype scale, $q_{p}$, of $150 \mathrm{~L} \cdot \mathrm{s}^{-1} \cdot \mathrm{m}^{-1}$ (the suggested lower limit in DVWK, 1996), $200 \mathrm{~L} \cdot \mathrm{s}^{-1} \cdot \mathrm{m}^{-1}$ and $250 \mathrm{~L} \cdot \mathrm{s}^{-1} \cdot \mathrm{m}^{-1}$ if a geometric scale of $1: 5$ is selected. This geometric scale will be applied throughout the whole paper when a dimensional quantity is shown for results.

Streamwise velocity, $u$, was measured at cross-sections using a propeller-type current meter (type: MC20, propeller diameter: $18 \mathrm{~mm}$, precision: $0.01 \mathrm{~m} \cdot \mathrm{s}^{-1}$ ) at the five cross-sections labeled A, B, C, D and E (Figure 2d) around the boulder sill S8. The sampling density was 48-56 points separated by $2.5 \sim 3 \times 4 \mathrm{~cm}$ in the $Y$ - and $Z$-directions, respectively, at sections $\mathrm{A}, \mathrm{B}, \mathrm{D}$ and $\mathrm{E}$, as well as $1.5 \times 1 \mathrm{~cm}$ at section $\mathrm{C}$. An acoustic Doppler Velocimeter (ADV) was not considered suitable for cross-sectional distributions owing to its restrictions when sampling near free surface, boundaries and the rough bottom.

Flow fields at longitudinal sections were obtained by means of Particle Image Velocimetry (PIV). The flow was seeded with 57- $\mu \mathrm{m}$ white particles. A planar 2D PIV apparatus (Intelligent Laser Applications $\mathrm{GmbH}$ ) with a double-cavity Nd-YAG $200 \mathrm{~mJ} /$ pulse laser of $532 \mathrm{~nm}$ wavelength was used to illuminate the flow field. Velocity measurements were taken in two vertical planes at the two openings at the upstream and downstream sides of the pool (plane L1: $Y=12.5 \mathrm{~cm}$ and plane L2: $Y=37.5 \mathrm{~cm}$, Figure 2d). A 12-bit high-resolution (1376 $\times 1040$ pixels) digital camera was used to image the flow. The measurements were made at a sampling rate of $5 \mathrm{~Hz}$ using interrogation size $=32$ pixels. The laser sheet was illuminated from the free surface instead of from the flume bottom due to its substrate of gravels.

Flow fields and turbulence distributions on horizontal planes were studied by conducting measurements of three-dimensional velocity components using a NorTek field ADV. 
Measurements were made at $Z=25-40 \mathrm{~mm}$ to compare the flow characteristics at the same, or very similar, relative depth, $Z^{*}=Z / h$, where $h$ is water depth. Measurements were conducted in pools between the sill pairs S4-S5 and S6-S7, in which the result of S6-S7 was a repeat test to study the influence of irregularity of structures consisting of boulders. The spacing of each measured point in the measured planes was $5-7 \mathrm{~cm}$ in $x$ - and $y$-directions. The sampling time of the ADV was $90 \mathrm{~s}$, and the sampling frequency was $25 \mathrm{~Hz}$. The sampling volume was obtained at a depth of $5 \mathrm{~cm}$ from the tip of the probe. The standard sampling volume is a cylinder of water with a diameter of $4.5 \mathrm{~mm}$ and a height of $5.6 \mathrm{~mm}$. The mean coefficients of correlation (COR) of the raw data are 60\%-81\%; a 70\% COR cutoff together with the phase-space despiking algorithm (Goring and Nikora, 2002; Wahl, 2003) is used as the filter.

To quantify the level of turbulence, we adopted turbulent kinetic energy (TKE) to give a physical metric. TKE is the mean kinetic energy per unit mass associated with eddies in turbulence and is estimated by $T K E=1 / 2 \cdot \sqrt{u^{\prime 2}+\bar{v}^{\prime 2}+{\overline{w^{\prime}}}^{2}}$, where $u^{\prime}, v^{\prime}$ and $w^{\prime}$ are fluctuating velocity components in $x, y$ and $z$ directions, and has been adopted in hydraulic tests on fishways (Puertas et al., 2004; Liu et al., 2006; Tarrade et al., 2008; Wang et al., 2010) and experiments on fish behavior (Nikora et al., 2003).

\section{> SITE OF FIELD INVESTIGATION}

The study site is located in the river system of Mangfall at the foot of the Alps in Germany. The bottom ramp in Kolbermoor represents a large-scale construction with active bed-load transport. It consists of two full-width pool-type ramps (Figures 1a and 14b), which replaced a six-meter-high spinnery weir to mitigate streambed erosion and to re-establish free passage for fish and other aquatic organics. The upper ramp is about $80 \mathrm{~m}$ long and $45-50 \mathrm{~m}$ wide, formed by 12 boulder sills; the lower ramp is about $60 \mathrm{~m}$ long and 33-42 m wide, formed by 11 boulder sills. The slopes of the two ramps are $2.9 \%$ (1:35) and 1.9\% (1:53), respectively, and the designed drop height between the two adjacent sills is $30 \mathrm{~cm}$. Between the two ramps, there is a reach approximately $80 \mathrm{~m}$ long to provide a resting zone and habitat for fish. The fish species near the ramp include chub (Leuciscus cephalus), grayling (Thymallus thymallus), barbel (Barbus barbus), brown trout (Salmo trutta f. fario), nase (Chondrostoma nasus), rainbow trout (Oncorhynchus mykiss), etc.

The ramp in Leitner is a partial-width pool-type ramp and it replaced part of an existing weir (Figure $1 \mathrm{~b}$ ), which is about $2 \mathrm{~m}$ high and $50 \mathrm{~m}$ wide. The ramp itself is about $10-20 \mathrm{~m}$ wide and $45 \mathrm{~m}$ long and was installed at the left bank to provide fish migration passage and to preserve part of the weir. The ramp in Leitner was constructed by armorstones, which were sealed with concrete at the weir side and were inserted without concrete at the bank side. The slope of the ramp is about $4 \%(1: 25)$ and the designed drop height is about $30 \mathrm{~cm}$. The fish species captured nearby were brown trout, grayling and bullhead (Cottus gobio). Both lists of fish species were provided by the Bavarian Fishing Association, which conducted the electric-fishing in 2006 (report not published).

\section{> METHOD OF FIELD INVESTIGATION}

A quantitative criterion stating that a facility should be passable for all fish species at least three hundred days a year (MUNLV, 2005; Dumont, 2006; DWA, 2006; Görlach, 2006; Schwevers, 2006) has frequently been reported in Germany recently. In this study, we adopted the criteria of hydraulics and geometry proposed by DWA (2006) for brown trout, grayling/dace and barbel, which presented in our study sites. The efficiency of fish passes expressed in number or percentage of fish passed by is not preferred; instead, effectiveness at five levels, i.e., very good, good, moderate, poor and bad, are presented. The corresponding criteria with the level "good" are listed in Table I; for the others see DWA (2006) or Wang (2008). 
Table I

Biological criteria in fish migration facilities suggested by DWA (2006): level of performance = B (good).

Tableau I

Critères pour les capacités de migration proposées par DWA (2006) : niveau de performance bon = B.

\begin{tabular}{|l|c|c|c|c|c|}
\hline Species & Scientific name & $H_{s, \min }(\mathrm{cm})$ & $B_{s, \min }(\mathrm{cm})$ & $\Delta h_{\max }(\mathrm{cm})$ & $V_{s, \max }\left(\mathrm{m} \cdot \mathrm{s}^{-1}\right)$ \\
\hline Brown trout & Salmo trutta & 40 & $20-40$ & 20 & 2.0 \\
\hline $\begin{array}{l}\text { Grayling } \\
\text { dace }\end{array}$ & $\begin{array}{c}\text { Thymallus thymallus / } \\
\text { Leuciscus leuciscus }\end{array}$ & 45 & $40-60$ & 15 & 1.7 \\
\hline Barbel & Barbus barbus & 50 & 60 & 13 & 1.6 \\
\hline
\end{tabular}

Note: $H_{s, \min }$, required minimum water depth; $B_{s, \min }$, required minimum slot width; $\Delta h_{\max }$, required maximum drop height; $V_{s, \max }$, required maximum velocity.

Note : $H_{s, \min }$, profondeur d'eau minimum requise ; $B_{s, \min }$, largeur minimale de la fente requise ; $\Delta h_{\max }$, différence de niveau d'eau maximal requise ; $V_{s, \max }$, vitesse maximale requise.

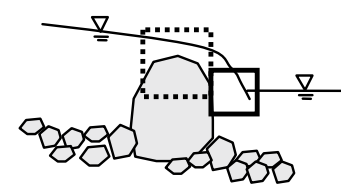

Longitudinal section

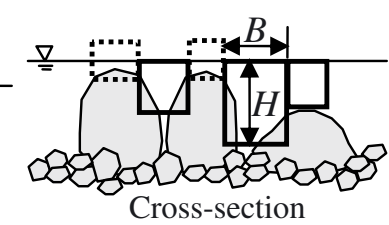

Criteria on potential passage slot: $B \geqslant 15 \mathrm{~cm}$ and $H \geqslant 10 \mathrm{~cm}$

Figure 3

Definition of dimensions and position of a potential passage slot and measurements.

Figure 3

Définition des dimensions et du positionnement de la fente potentielle de passage et ses mesures.

The studied discharge was selected to be 30 -days-nonexceedence-discharge $\left(Q_{30}\right.$, representing the low flow conditions) and 330-days-nonexceedence-discharge $\left(Q_{330}\right.$, representing the high flow conditions); in addition, mean annual flow $(M Q)$ was also investigated to study the average flow conditions. The discharges, $Q_{30}, M Q$ and $Q_{330}$, obtained from the historic records at the study sites are $3.06,17.4$ and $36.9 \mathrm{~m}^{3} \cdot \mathrm{s}^{-1}$, respectively, for the full-width ramp in Kolbermoor and 2.25, 4.66 and $7.83 \mathrm{~m}^{3} \cdot \mathrm{s}^{-1}$, respectively, for the partial-width ramp in Leitner.

In the fieldwork, maximum velocity $\left(V_{s}\right)$, water depth $\left(H_{s}\right)$, slot width $\left(B_{s}\right)$ and water level difference (drop height, $\Delta h$ ) at all potential passage slots of each boulder sill were measured. A slot was recognized as a potential passage if the width of water surface at the slot $\left(B_{s}\right)$ was greater than $15 \mathrm{~cm}$ and the water depth where slot width measurement was taken $\left(H_{s}\right)$ was greater than $10 \mathrm{~cm}$ (as shown in Figure 3 and the yellow arrow in Figure 4). Due to shallow water depth, overflow at boulders (dotted box and red arrows in Figures 3 and 4) does not provide fish passage and thus no measurement was made. Instead of measuring all slots, the above rule identified hundreds of slots as potential passages for measurement.

Velocity measurements were conducted using propeller current meters at positions where the maximum velocity occurs $\left(V_{s}\right)$, which was at the end of flow contraction downstream from a slot and was determined from individual observation. Velocity was measured at near the bottom position $(Z=2.8 \mathrm{~cm})$ in the first investigation $(M Q)$. In the second investigation $\left(Q_{30}\right)$, to verify the existence of various vertical corridors for fish with different swimming ability, we conducted measurements at two depths $(Z=2.8 \mathrm{~cm}$ and $10 \mathrm{~cm})$. Because the measurement from the first investigation showed relatively homogeneous flow conditions between sills, about half of the sills were selected for the second investigation. 


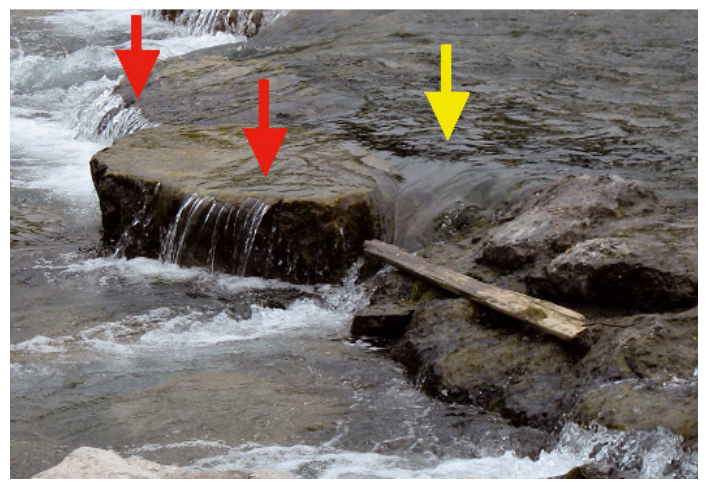

\section{Figure 4}

Recognition of potential passage slots - yellow arrow: potential passage slot; red arrow: overflow at boulders.

\section{Figure 4}

Reconnaissance des points de passage - flèche jaune : passage potentiel; flèche rouge : débordement sur les galets.
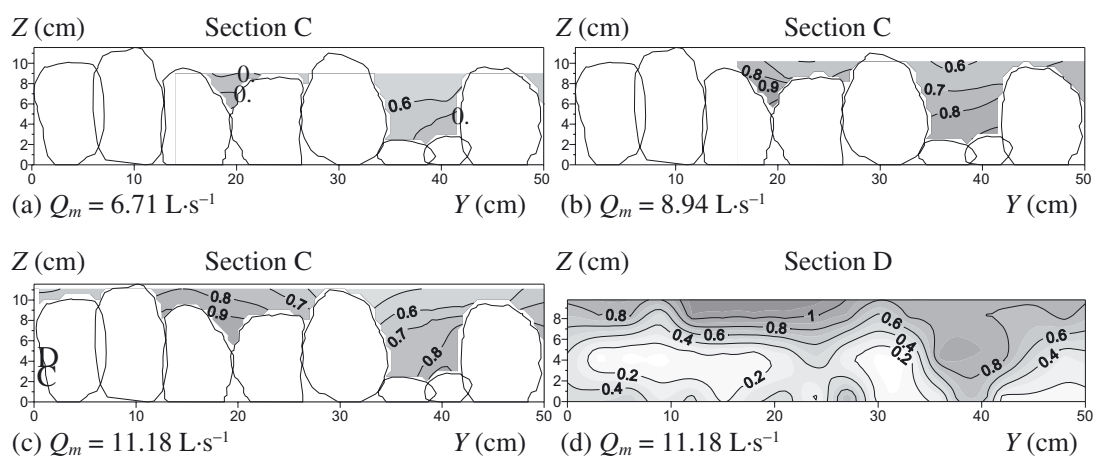

\section{Figure 5}

Normalized streamwise velocity $\left(u^{*}=u / V_{t m}\right)$ distributions at cross-sections $C$ and $D$ (see Figure $2 d$ ) around sill S8.

\section{Figure 5}

Distributions des vitesses normalisées $\left(u^{*}=u / V_{t m}\right)$ aux sections C et D (cf. Figure $\left.2 \mathrm{~d}\right)$ au niveau du seuil S8.

Other common parameters for fishways, e.g. minimum length and width of pools, were not examined in this study for NLFs, since they were apparently greater than the threshold values, e.g. minimum length of pools greater than $4 \mathrm{~m}$ and minimum width of pools greater than $3 \mathrm{~m}$ for barbel, at the level of "very good".

\section{RESULTS OF THE SCALE MODEL TEST}

\section{> STREAMWISE VELOCITY DISTRIBUTION AND FLOW FIELD IN THE LONGITUDINAL PLANE}

For pool-type fish passes, the theoretical maximum velocity $\left(V_{t m}\right)$ can be estimated by the equation $V_{t m}=\sqrt{2 g \Delta h}$, where $g$ is the gravitational acceleration. Figure 5 illustrates some results of the streamwise velocity normalized by the theoretical maximum velocity, $u^{*}=u / V_{t m}$, at the cross-sections $C$ and D. Section $D$ was selected to approach the location where the maximum velocity $\left(V_{\max }\right)$ occurs to obtain a representative $V_{\max } \cdot u^{*}$ at a slot was about $0.5-0.9$ for various discharges (Figures $5 \mathrm{a}-5 \mathrm{c})$. The maximum $u_{\max }^{*}$ near the slot $(Y \approx 34-43 \mathrm{~cm})$ at section $C$ was $0.8,0.93$ and 0.98 , and at section $D$ was $0.82,0.76$ and 0.95 , respectively, for the three discharges. This gives evidence that the maximum velocity ranges from $0.8 \mathrm{~V}_{t m}$ to nearly $1.0 \mathrm{~V}_{t m}$ but does not exceed the theoretical maximum value. The data also show two interesting phenomena: 1 ) different overtopping conditions with discharges; 2 ) the maximum 
velocity might not necessarily occur along the plunging flow from the slots. Overtopping was observed at $Y \approx 20 \mathrm{~cm}$ for low discharge (Figure 5a), and spread over almost the whole cross-section with high discharge (Figure 5c), in which one more potential passage slot was created due to increased water depth. Velocity at these overtopping zones was even greater than values around slots and could be nearly $10 \%$ greater (Figure $5 \mathrm{~d}, Y \approx 18 \mathrm{~cm}$ ) than $V_{\mathrm{tm}}$. Flow fields at longitudinal sections are shown in Figure 6 . The color contours indicate the magnitude of plane velocity $V_{x z}^{*}=V_{x z} / V_{t m}$ and overlap with streamlines. Flow pattern at L1 (upstream side is the slot) was very similar between S4-S5 and S6-S7, as well as for the three discharges: the streamlines were nearly parallel to each other without recirculations. However, in S4-S5 the water jet flowed downwards and the high velocity occurred close to the flume bottom; on the contrary, in S6-S7 the jet entered the pool horizontally with the high-velocity region close to the free surface. At the section L2 (downstream side is the slot), vertical recirculations rotating counterclockwise can be observed (Figure 6a). The centers of the recirculations were between $X=5 \mathrm{~cm}$ and $X=10 \mathrm{~cm}$. Flow near the downstream sill was upwelling, which was caused by the smaller stones forming the threshold at the bottom. When discharge increased, the recirculation moved downstream and then vanished at high discharge (Figures 6a-6c). The upwelling at the downstream side was mitigated, i.e. $w$ decreased, with increasing discharge. A very small recirculation with complicated streamlines was created at $X \approx 17 \mathrm{~cm}$ in S4-S5 with $Q_{m}=8.94 \mathrm{~L} \cdot \mathrm{s}^{-1}$, which reveals a three-dimensional flow in the neighborhood. Between sills S6-S7, the flow was different from those between S4-S5. The recirculation also moved toward downstream but did not vanish with discharge. The recirculation with $Q_{m}=11.18 \mathrm{~L} \cdot \mathrm{s}^{-1}$ changed its rotation direction and became clockwise. This can be explained by strongly increased $V_{x}$ near the free surface forcing the water near the surface to flow downstream and, therefore, the recirculation changed its direction. Contrary to S4-S5, the upwelling was much more strengthened.

The results for S4-S5 and S6-S7 reveal the fact that flow fields in different pools can develop very differently in NLFs, in both flow topology and velocity, while applying similar boulder sills with irregular structures coming from natural materials of boulders.

\section{> FLOW FIELD AND TURBULENT KINETIC ENERGY IN THE HORIZONTAL PLANE}

The isocontours of the normalized mean velocity, $V_{x y}^{*}=V_{x y} / V_{t m}$, in the $X Y$-plane at $Z^{*}=0.34$ are shown in Figure 7. Flow topology does not show significantly different patterns between the three discharges and, therefore, the result shown in the figure is for $Q_{m}=8.94 \mathrm{~L} \cdot \mathrm{s}^{-1}$ only. The flow pattern contains two parts: a water jet from the slot that passes across the pool with decreasing velocity, and a low-velocity zone occupying nearly half of the pool close to the downstream slot side. The maximum of $V_{x y}^{*}$ was around $0.7-0.8$. The flow started to change its direction (the meandering flow created by the setup of boulders) when very close to the downstream sill at $X \approx 25 \mathrm{~cm}$. $V_{x y}^{*}$ in the low-velocity zone was about 0.2 or less, which provided a large potential resting zone for fish. Basically, flow patterns between S4-S5 and S6-S7 were similar but some minor differences can be observed. Firstly, the maximum velocity in the water jet was 0.8 for S4-S5 and 0.7 for S6-S7; secondly, we observed different dimensions and distribution of low-velocity zones: for S4-S5 we see a large zone between $Y=0-25 \mathrm{~cm}$; for S6-S7 we see a smaller zone between $Y=0-20 \mathrm{~cm}$ and another small zone between $Y=43-50 \mathrm{~cm}$.

The turbulent kinetic energy is presented in a scalar quantity by $T K E^{1 / 2}$. For S4-S5, high $T K E^{1 / 2}$ distributed downstream of the sills and reached high magnitudes ranging from 26$30 \mathrm{~cm} \cdot \mathrm{s}^{-1}$ near both sidewalls (Figure 8a). Considering the flow fields shown in Figure 7 , we observed that the the mean velocity of flow was relatively low near the sidewalls, but more turbulent with greater $T K E^{1 / 2}$. However, the distribution of $T K E^{1 / 2}$ was different from that for S6-S7. TKE ${ }^{1 / 2}$ reached high magnitudes immediately below the sill S6, which resulted from the irregular cross-section in various sills: for S6, the boulders in the middle of the sill were relatively smaller, and therefore stronger overtopping flow occurred and resulted in high 


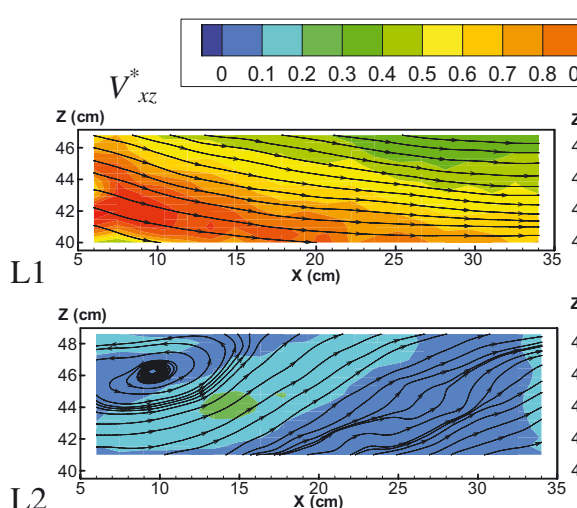

(a) $\mathrm{S} 4-\mathrm{S} 5, Q_{m}=6.71 \mathrm{~L} \cdot \mathrm{s}^{-1}$

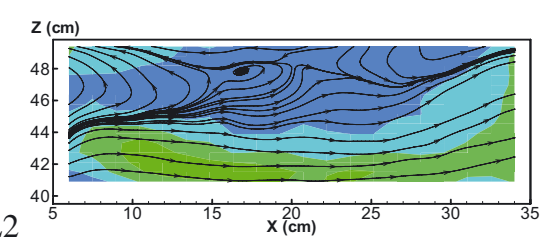

(b) S4-S5, $Q_{m}=8.94 \mathrm{~L} \cdot \mathrm{s}^{-1}$

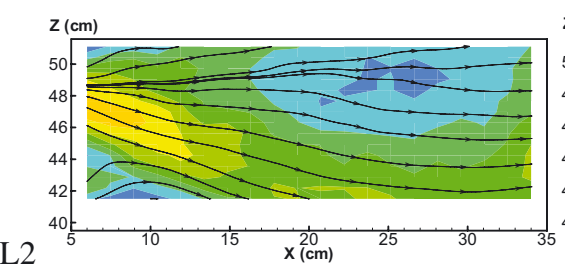

(c) $\mathrm{S} 4-\mathrm{S} 5, Q_{m}=11.18 \mathrm{~L} \cdot \mathrm{s}^{-1}$
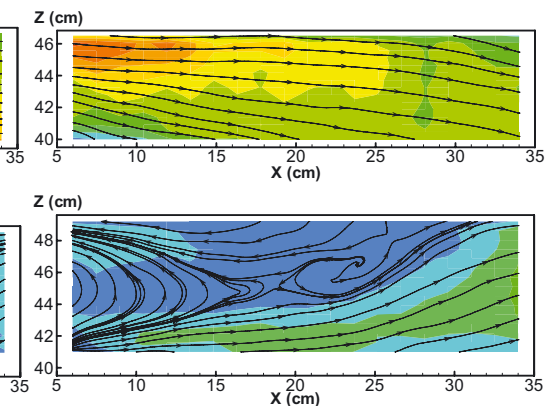

(d) S6-S7, $Q_{m}=6.71 \mathrm{~L} \cdot \mathrm{s}^{-1}$

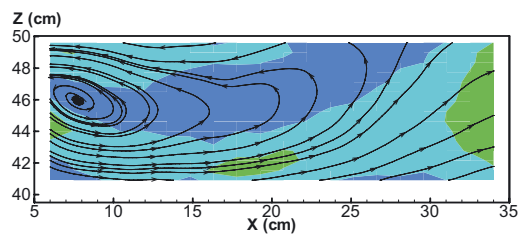

(e) S6-S7, $Q_{m}=8.94 \mathrm{~L} \cdot \mathrm{s}^{-1}$

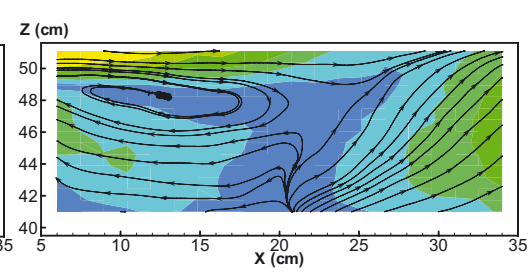

(f) S6-S7, $Q_{m}=11.18 \mathrm{~L} \cdot \mathrm{s}^{-1}$

\section{Figure 6}

Velocity $\left(V_{x z}^{*}\right)$ distributions at the longitudinal sections L1 and L2 (see Figure 2d).

\section{Figure 6}

Distributions de vitesse $\left(V_{x z}^{*}\right)$ aux sections longitudinales L1 et L2 (cf. Figure $\left.2 d\right)$.

turbulence. The means of $T K E^{1 / 2}$ in the whole pool are similar in the two configurations; they are $22.7 \mathrm{~cm} \cdot \mathrm{s}^{-1}$ and $21.7 \mathrm{~cm} \cdot \mathrm{s}^{-1}$ for S4-S5 and for S6-S7, respectively.

\section{RESULTS OF THE FIELD INVESTIGATION}

\section{> FULL-WIDTH RAMP IN KOLBERMOOR}

The measured average drop heights were $18.5 \mathrm{~cm}$ and $11 \mathrm{~cm}$, instead of $30 \mathrm{~cm}$ in the design, at the upper and the lower ramps, which correspond to the theoretical maximum velocities of $1.91 \mathrm{~m} \cdot \mathrm{s}^{-1}$ and $1.47 \mathrm{~m} \cdot \mathrm{s}^{-1}$, respectively. Figures 9 and 10 show flow velocity and water depth at each potential passage slot along each boulder sill of the whole ramp, i.e. the distribution of flow velocity and water depth along each sill.

Velocity (at $Z=2.8 \mathrm{~cm}$ ) at the upper ramp ranged from $0.8-1.9 \mathrm{~m} \cdot \mathrm{s}^{-1}$, and $0.5-1.8 \mathrm{~m} \cdot \mathrm{s}^{-1}$ for $M Q$ and $Q_{30}$, respectively, and at the lower ramp ranged from $0.6-1.7 \mathrm{~m} \cdot \mathrm{s}^{-1}$, and $0.5-1.6 \mathrm{~m} \cdot \mathrm{s}^{-1}$ for $M Q$ and $Q_{30}$, respectively. Apparently, for the three representative fish species, the measured velocity at slots was much less than the maximum threshold $\left(V_{s, \max }=1.6-2.0 \mathrm{~m} \cdot \mathrm{s}^{-1}\right)$ and was not a critical parameter. The maximum of the measured velocity, $V_{s} \approx 1.6-1.9 \mathrm{~m} \cdot \mathrm{s}^{-1}$, across the whole sill was close to the theoretical value. 


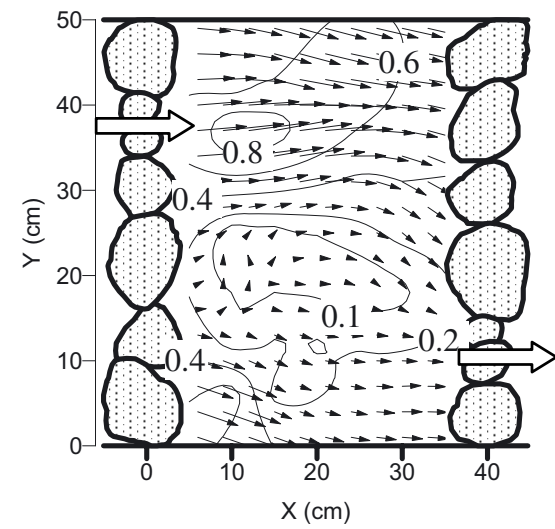

(a) S4-S5

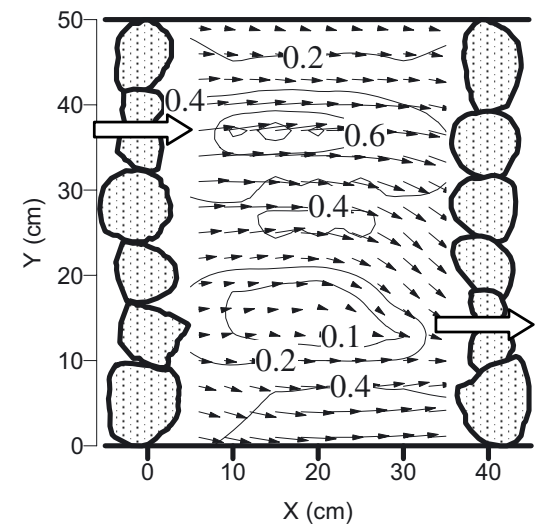

(b) S6-S7

Figure 7

Isocontours of mean flow $\left(V_{x y} / V_{t m}\right)$ in pools: $S=1: 30, Q_{m}=8.94 L \cdot S^{-1}, Z^{*}=0.34$ (white arrows indicate the locations of the openings).

\section{Figure 7}

Isocontours du flux moyen $\left(V_{x y} / V_{t m}\right)$ dans les bassins : $S=1: 30, Q_{m}=8,94 \mathrm{~L} \cdot \mathrm{S}^{-1}, Z^{*}=0,34$ (les flèches blanches indiquent l'emplacement des ouvertures).

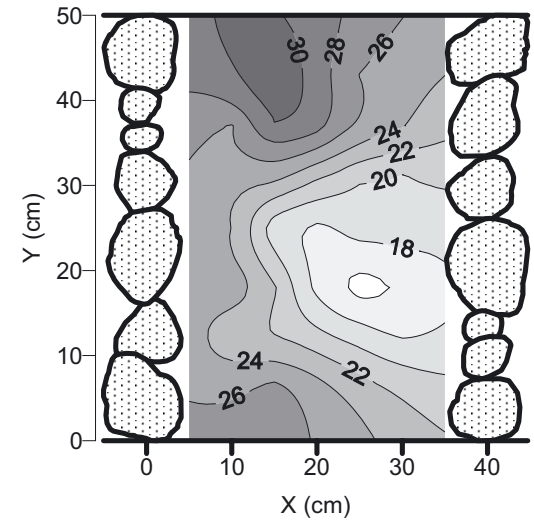

(a) S4-S5

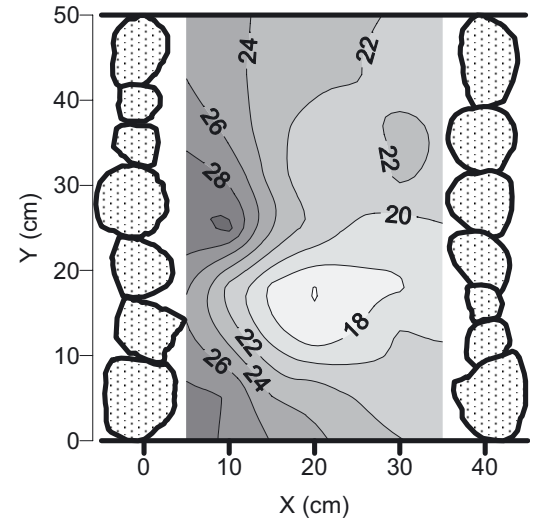

(b) S6-S7

Figure 8

Isocontours of $\operatorname{TKE}^{1 / 2}\left(\mathrm{~cm} \cdot \mathrm{s}^{-1}\right)$ in pools: $S=1: 30, Q_{m}=8.94 \mathrm{~L} \cdot \mathrm{s}^{-1}, Z^{*}=0.34$.

Figure 8

Isocontours de $T K E^{1 / 2}\left(\mathrm{~cm} \cdot \mathrm{s}^{-1}\right)$ dans les bassins : $S=1: 30, Q_{m}=8,94 \mathrm{~L} \cdot \mathrm{s}^{-1}, Z^{*}=0,34$.

Fieldwork at $Q_{330}$ was conducted only on the right shore of the upper ramp in Kolbermoor due to security considerations. The results show that velocity at the upper ramp ranged from $0.7-1.6 \mathrm{~m} \cdot \mathrm{s}^{-1}$ and was no greater than velocity under $M Q$ or $Q_{30}$.

Most of the measured water depth at slots was between 10 and $40 \mathrm{~cm}$ (Figure 10) for the two discharges. They were $29 \pm 12.5 \mathrm{~cm}$ (mean \pm standard deviation) and $30 \pm 12 \mathrm{~cm}$ for $M Q$ at the upper and lower ramp, respectively, as well as $23.7 \pm 8.5 \mathrm{~cm}$ and $22.7 \pm 7 \mathrm{~cm}$ for $Q_{30}$, respectively. Considering brown trout with its required minimum water depth $\left(H_{s, \min }=40 \mathrm{~cm}\right)$, only at sills Nos. 8, 7 and $4-1$ at the lower ramp, and sills Nos. 11, 9-3, and 1 was the water depth greater than or equal to $H_{s, \text { min }}$; during low flow, water depth over nearly the whole ramp was too shallow. $H_{s, \text { min }}$ for the other two species is $45 \mathrm{~cm}$ for grayling/dace and $50 \mathrm{~cm}$ for barbel, respectively. It indicates that grayling, dace, barbel and other species with similar 


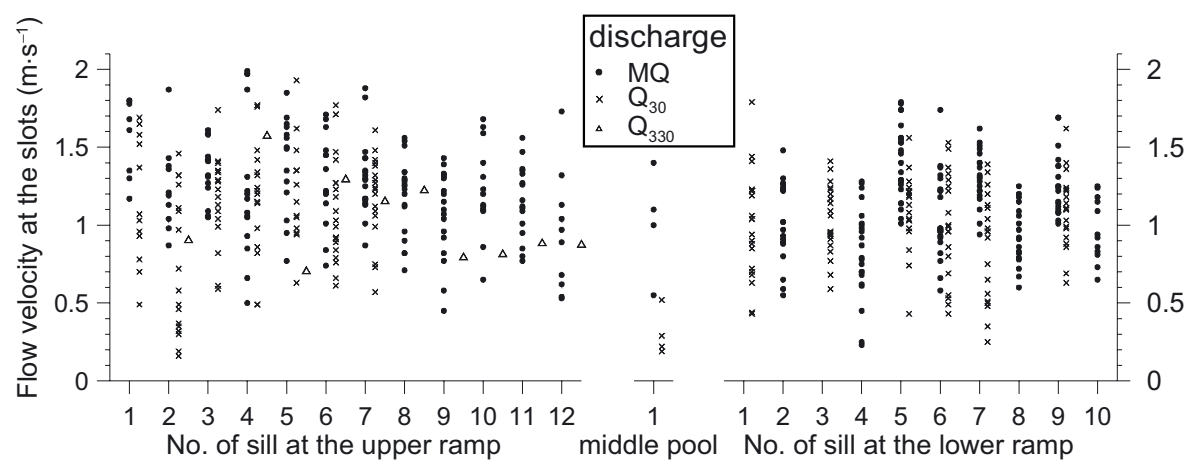

\section{Figure 9}

Velocity at slots at the upper and the lower ramps of the full-width ramp in Kolbermoor: $X$-axis indicates numbering of boulder sills from upstream to downstream (see Figure 14b).

\section{Figure 9}

Vitesse dans les fentes dans les rampes supérieures et inférieures de la passe de Kolbermoor: I'axe des $X$ indique les numéros des seuils de l'amont vers l'aval (cf. Figure 14b).

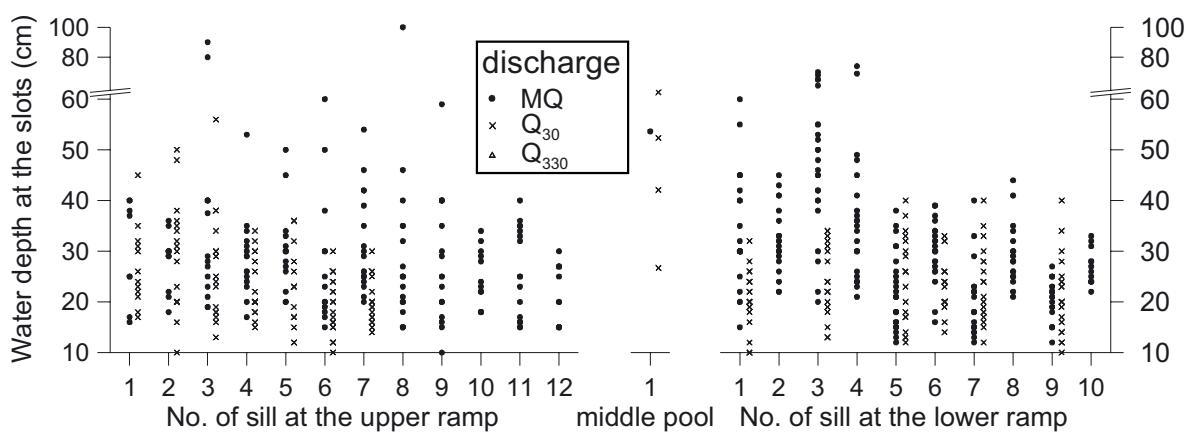

\section{Figure 10}

Water depth at slots at the upper and the lower ramps of the full-width ramp in Kolbermoor.

\section{Figure 10}

Épaisseur d'eau dans les fentes dans les rampes supérieures et inférieures de la passe de Kolbermoor.

swimming ability suffer more difficulty in passing through the ramp due to too shallow water at slots.

Most of the measured slot widths ranged from 15-45 cm and 15-55 cm for the upper/lower ramps, respectively. However, unlike water depth, there were many slots with much greater width in the ranges of $60-200 \mathrm{~cm}$ and $60-100 \mathrm{~cm}$ at the upper/lower ramps. Therefore, slot width in the structure of ramps is not a critical parameter for brown trout (required minimum slot width, $\left.B_{s, \min }=20-40 \mathrm{~cm}\right)$ and grayling/dace $\left(B_{s, \min }=40-60 \mathrm{~cm}\right)$; however, for barbel with $B_{s, \min } \geq 60 \mathrm{~cm}$, slots at sills Nos. $10,7-6$ and 3-1 of the lower ramp, and sills Nos. 11-10 and $7-5$ of the upper ramp were too narrow.

\section{> PARTIAL-WIDTH RAMP IN LEITNER}

The results of $V_{s}, H_{s}, B_{s}$ and $\Delta h$ at the partial-width ramp in Leitner are shown in Figure 11. The measured velocity was in the range of $0.6-1.8 \mathrm{~m} \cdot \mathrm{s}^{-1}$ at the most upstream (Nos. 3-1) and downstream (Nos. 13-11) sills and $0.9-1.7 \mathrm{~m} \cdot \mathrm{s}^{-1}$ at the middle sills (Nos. 10-4). In contrast to the measured velocity at the full-width ramp in Kolbermoor, we saw inhomogeneous velocity distribution between sills along the whole ramp. Similar to the ramp in Kolbermoor, velocity in the ramp in Leitner was basically not a critical parameter under either mean or low flow conditions. 


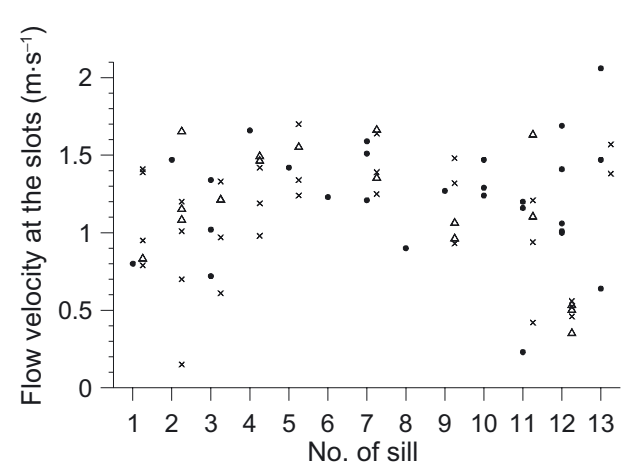

(a) Velocity, $V_{s}$

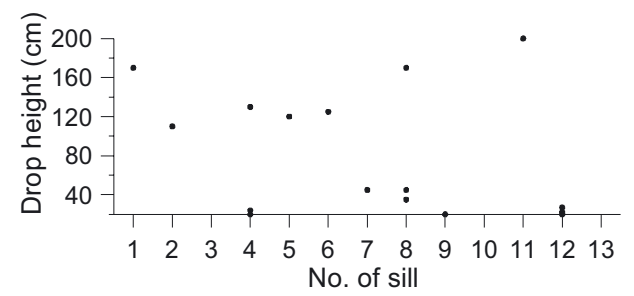

(c) Drop height, $\Delta h$

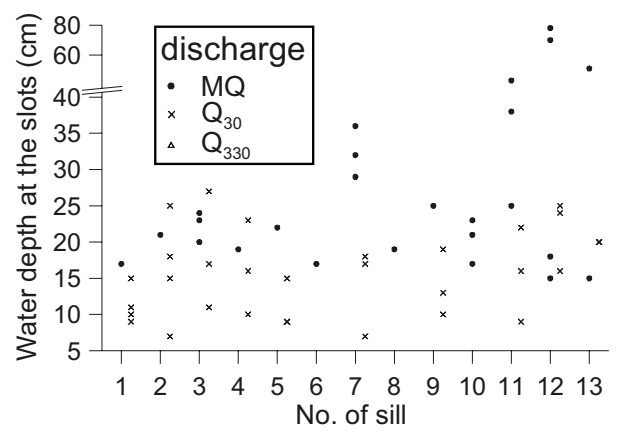

(b) Water depth, $H_{s}$

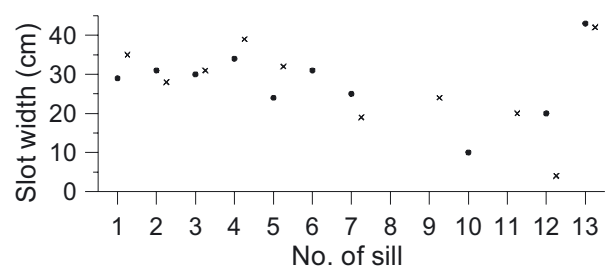

(d) Slot width, $B_{s}$

\section{Figure 11}

Velocity, water depth, drop height and slot width at slots at the partial-width ramp in Leitner: X-axis indicates numbering of boulder sills from upstream to downstream.

\section{Figure 11}

Vitesse, profondeur d'eau et hauteur de chute aux passages dans la passe de Leitner : l'axe des $X$ indique la numérotation des seuils en blocs de l'amont vers l'aval.

Most of the measured water depths were between 15-25 cm for $M Q$ and 8-25 cm for $Q_{30}$, except at sills Nos. 13-11 with much greater $H_{s} \approx 40-65 \mathrm{~cm}$. The sills that complied with the criteria for brown trout were sills Nos. 13-11, and for grayling/dace or barbel were sills Nos. 13-12 during mean flow. During low flow, none of the sills could provide sufficient water depth for all species. The width of the slots was generally not a critical factor for brown trout and grayling/dace, except at sill No. 9 with $B_{s}=20 \mathrm{~cm}$; however, for barbel, sills Nos. 7, 9 and 12 were less than the corresponding $B_{s, \min }$.

Drop height at this ramp was about $30 \mathrm{~cm}$ at sills Nos. 1-6, about $20 \mathrm{~cm}$ at sills Nos. 7-12, and an extreme value of greater than $40 \mathrm{~cm}$ at sill No. 13 (Figure 11c). All the measured drop heights were much greater than the threshold values for the three representatives. However, drop height was used to estimate the maximum flow velocity at narrow openings in passage. Whereas the measured velocity was adequate for fish to migrate, it is not necessary to examine drop height afterwards, if $V_{s}$ is measured.

\section{$>$ VERTICAL CORRIDOR}

Figure 12 shows the cumulative histograms of velocity measured at the two water depths $(Z=2.8$ and $10 \mathrm{~cm})$ and the two discharges $\left(M Q\right.$ and $\left.Q_{30}\right)$ in the full-width ramp in Kolbermoor. In general, velocity at the upper ramp was slightly greater than at the lower ramp due to its greater bottom slope of $2.9 \%$ compared with $1.9 \%$ of the lower ramp. Between mean flow $M Q$ and low flow $Q_{30}$, the cumulative histograms (Figure 12a) show that for $V_{s}$ greater than $1.0 \mathrm{~m} \cdot \mathrm{s}^{-1}, V_{s}$ measured at $M Q$ was approximate $0.2-0.3 \mathrm{~m} \cdot \mathrm{s}^{-1}$ greater than $V_{s}$ measured at $Q_{30}$. Velocity at $Z=10 \mathrm{~cm}$ and $Z=2.8 \mathrm{~cm}$ (Figure 12b) measured at $Q_{30}$ had nearly the same distribution, except when velocity was less than $0.8-0.9 \mathrm{~m} \cdot \mathrm{s}^{-1}$. Since velocity of $1.6 \mathrm{~m} \cdot \mathrm{s}^{-1}$ is the lowest critical value for all fish species, study of the vertical velocity profile 


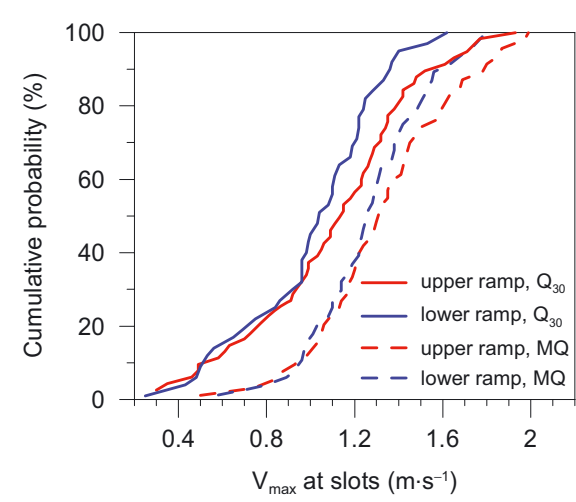

(a) Velocity at $Z=2.8 \mathrm{~cm}$

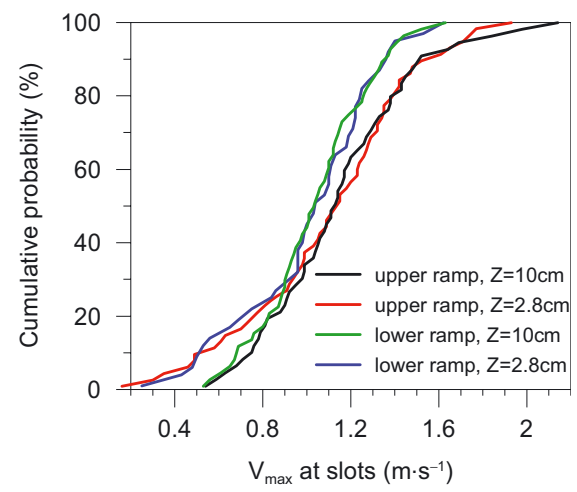

(b) Velocity at discharge $=Q_{30}$

\section{Figure 12}

Cumulative probability curves of velocity measured at the full-width ramp Kolbermoor.

Figure 12

Courbes de probabilité cumulée des vitesses mesurées dans la passe de Kolbermoor.

in such a field investigation is not necessary and velocity measurements at different water depths can be neglected.

\section{DISCUSSION}

\section{> TURBULENT KINETIC ENERGY IN THE HORIZONTAL PLANE}

To compare with experiments conducted by other authors, we converted $T K E^{1 / 2}$ into a dimensionless metric $-T K E^{*}=T K E^{1 / 2} / V_{t m}$ and obtained $T K E^{*}=0.025-0.038$ for S4-S5 and $T K E^{*}=0.022-0.030$ for S6-S7. TKE ${ }^{*}$ in the studies of vertical slot fishways range from 0.01-0.11 for $S=5.7 \%$ (Puertas et al., 2004), 0.01-0.08 for $S=5.06 \%$ (Liu et al., 2006), and $0.01-0.10$ for $S=5 \%$ (Tarrade et al., 2008), respectively. Compared with these previous studies, the values of $T K E^{*}$ in our study lie within their range, with the maximum only approximately $40 \%$ of their values.

\section{>FLOW FIELD BETWEEN DESIGN, MODEL TEST AND REALITY}

The overtopping at boulder sills of bottom ramps varies with discharges in rivers, and therefore the number of passage slots and their dimensions vary, too. The existence and the rotation direction of vertical recirculations also changed accordingly. In addition, free overflow and submerged overflow affected the maximum velocity. For example, flow velocity at sill No. 13 at the partial-width ramp ranged from $0.64-2.06 \mathrm{~m} \cdot \mathrm{s}^{-1}$ under mean flow but $1.28-1.63 \mathrm{~m} \cdot \mathrm{s}^{-1}$ under low flow, in which the minimum value of velocity under low flow was greater than that under mean flow. The reason is that flow at this slot was submerged overflow for mean discharge and free overflow for low discharge. The free overflow had greater drop height and its velocity increased with discharge.

The common adopted drop in a technical fishway is between 15 and $30 \mathrm{~cm}$ and the theoretical maximum velocity was $1.72 \mathrm{~m} \cdot \mathrm{s}^{-1}$ and $2.42 \mathrm{~m} \cdot \mathrm{s}^{-1}$, respectively. Our model test showed the maximum velocity ranging between $0.8 V_{t m}$ and $1.0 V_{t m}$, while in fieldwork, this range is even greater.

Take the mean flow conditions at the full-width ramp in Kolbermoor as an example. With a designed drop height of $30 \mathrm{~cm}$, the measured drop height was only $18.5 \mathrm{~cm}$ and $11 \mathrm{~cm}$ for the upper and lower ramps, respectively. Using the measured drop height to calculate $V_{t m}$, 


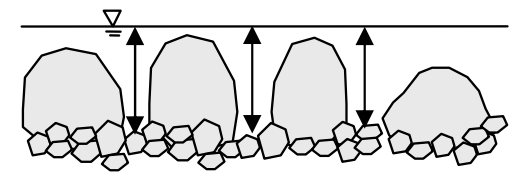

(a) Kolbermoor

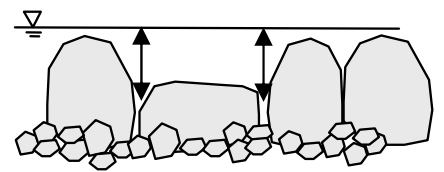

(b) Leitner

\section{Figure 13}

Difference in sill structure: (a) Full-width ramp in Kolbermoor - slots randomly created between boulders, multiple openings. (b) Partial-width ramp in Leitner - arranging one or two openings at a sill by flat boulders, water depth is ensured in pools but not at slots (sketch of cross-section).

\section{Figure 13}

Différences de structure de seuil : (a) passe de Kolbermoor - fentes créées au hasard entre les blocs, ouvertures multiples; (b) passe de Leitner - une ou deux ouvertures par seuil par bloc plat, l'épaisseur d'eau est garantie dans les bassins mais pas dans les passages (croquis de section transversale).

the measured maximum velocities were about $0.42-0.99 V_{t m}$ and $0.17-1.16 V_{t m}$ at the upper and lower ramps, respectively. Note that due to limitations in field monitoring, it was very difficult to ensure every single measurement represented the maximum velocity, and thus resulted in lower velocity at the lower limits (the 0.42 and 0.17 values). For the higher limits, the measured velocities $\left(0.99 \mathrm{~V}_{t m}\right.$ and $\left.1.16 \mathrm{~V}_{t m}\right)$ were close to 1 , which were similar to the experimental results.

The main problem in providing fish passage at NLFs is water depth. Although both ramps in this study are categorized as pool-type ramps according to their structure, water depth, $H_{s}$, at the partial-width ramp in Leitner $\left(H_{s} \sim 15-25 \mathrm{~cm}\right.$ for $M Q$ and 8-25 cm for $\left.Q_{30}\right)$ was much less than that at the full-width ramp in Kolbermoor $\left(H_{s} \sim 10-40 \mathrm{~cm}\right.$ in general) due to different dimensions and discharges, as well as the boulder arrangement to form a sill. As illustrated in Figure 13, at the full-width ramp in Kolbermoor, most slots were formed accordingly between two boulders, and therefore along the whole span of a sill, multiple potential passage slots can be observed randomly. At the partial-width ramp in Leitner, openings were created by arranging boulders at certain points along a sill, and therefore slots were found only around these openings.

Figure 14 shows an example of a bottom ramp in the blueprint and after construction. Each pool of the ramp in the design was arranged downstream of two pools to create its natural dynamics. After construction, the ramp looks like a cascade of pools separated by parallel boulder sills with some small pools inside each cascade. Besides, the number of boulder sills changed from 6 in the blueprint to 11 in the built structure, and thus changed the drop height, which is an important parameter in fishway design.

\section{> PROCEDURES OF FIELD INVESTIGATION AND VERIFICATION OF FREE PASSAGE}

Although there is an "at least 300 days a year passable" criterion on fish pass performance often mentioned in Germany, there is no operating procedure to provide data to demonstrate the effectiveness of fish passes under various flow conditions, which is a common problem for NLFs to run during low flow periods. Ideally the process of free passage assessment is to conduct biological monitoring, so that movement of various fish species can be clearly quantified. The traditional and the most economic way is fish capture-mark-recapture. Capture and mark can be easily done by means of electric-fishing and tagging, e.g. dye; recapture is, however, difficult to conduct at large-dimension NLFs such as the full-width ramp in Kolbermoor. Using telemetry to tag fish is another method of efficiency assessment; however, the difficulty lies in economic feasibility. The monitoring procedures on hydraulic/geometric aspects we present in this study provide a feasible method at NLFs. In general, at a conventional fishway, a hydraulic investigation can be conducted easily by one person throughout 


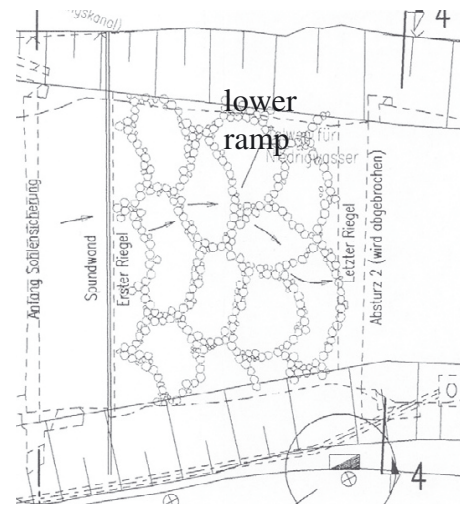

(a) blueprint

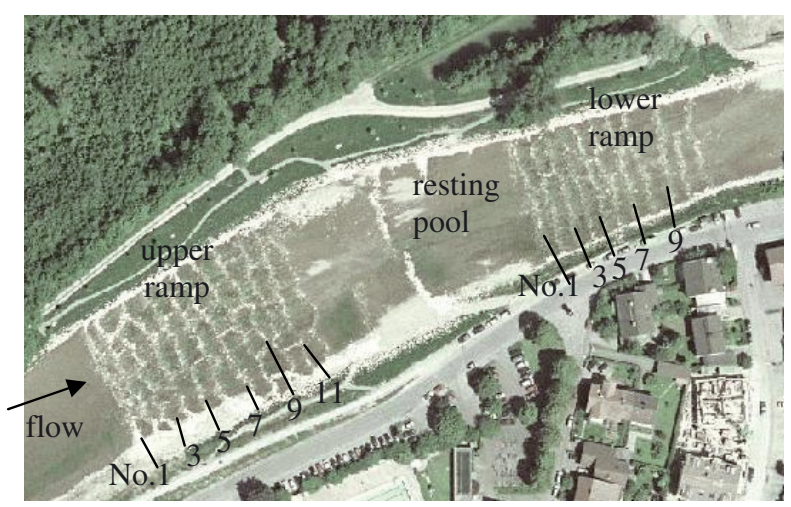

(b) Bird's eye view in situ

\section{Figure 14}

An example of a bottom ramp in the blueprint and after construction - the lower ramp of the full-width ramp in Kolbermoor: (a) the ramp was designed as multiple pools to dissipate energy homogeneously during flood; (b) the construction is closer to a series of boulder sills in reality. Boulder sills are numbered from upstream to downstream for studying free passage (source: blueprint - Water Resources Bureau Rosenheim; photo - Bayern Viewer).

\section{Figure 14}

Un exemple de passe sur plan et après construction - la partie aval de la passe de Koblermoor : (a) de multiples bassins constituent la passe pour dissiper l'énergie de façon homogène pendant les crues; (b) cette passe est en réalité à proximité d'autres seuils en blocs (source : plan - bureau des ressources hydrauliques Rosenheim; photo - Bayern Viewer).

the whole construction in a short time (limited openings, unnecessary to measure dimensions of openings, easy access to flow). Although fieldwork at NLFs is more labor-intensive and time-consuming than conventional fishways, it is more economical and less difficult than biological monitoring. In addition, for bottom ramps, it is ideal if hydraulic/geometric investigations can be conducted before the first flood, which could potentially change the structure. Fieldwork for $Q_{330}$ was conducted only along the right shore of the upper ramp at the fullwidth ramp in Kolbermoor. The data gathered for $Q_{330}$ show that velocity along the shoreline during high flow was lower than the upper limits for all the representative species. However, pools between sills at high flow provided very limited resting zones and flow was very turbulent and turbid by observation. We therefore suggest that, in addition to velocity and water depth, for high flow conditions, parameters such as turbulence and turbidity could be an important component to be investigated.

It was challenging to collect sufficient staff and equipment for this fieldwork during high flood flows. The high discharge and water stages posed high risk to safety and thus limited the sampling to the shoreline. Due to the small number of samples, it could be statistically difficult to validate the appropriate velocity for discharge $=Q_{330}$ in the field. In some cases, the conditions were too rough to collect any sample and thus it was impossible to validate the hydraulics at all.

Evidence of the biological free passage at bottom ramps in nature is difficult to collect (Gebler, 1991). In this study we suggest a hydraulic/geometric investigation to collect sufficient evidence for fish free passage at NLFs in a feasible way. Under our approach, the hypothesis, or rather "belief" that a NLF ensures passage for more or all fish species can therefore be accepted (e.g. the full-width ramp in Kolbermoor), or rejected (e.g. the partial-width ramp in Leitner) quantitatively.

To appropriately interpret the relationship of the "theoretical maximum velocity" of flow near an opening and the "measured maximum velocity" in situ is also an issue. The velocity distribution shown in Figure 9 appears to be close to or less than $V_{t m}$; however, the result should not be taken as an underestimation due to measurement error. We believe our approach 


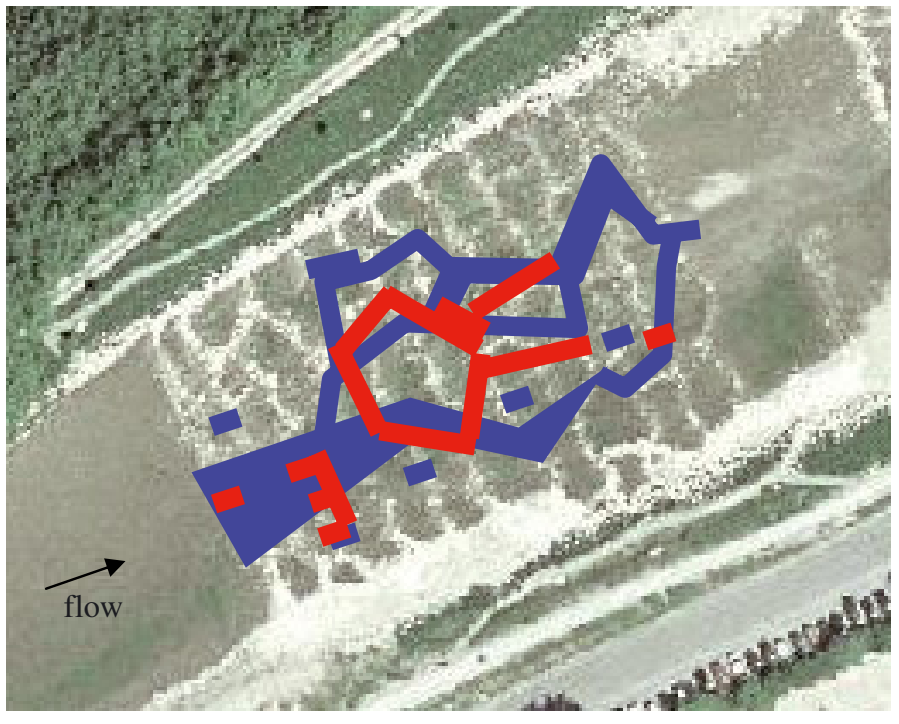

\section{Figure 15}

Example of sensitivity analysis on criteria selection: free passage for brown trout at the upper ramp of the full-width ramp in Kolbermoor under mean flow condition - red zone: $H_{s, \min }=40 \mathrm{~cm}$; blue zone: $H_{s, \min }=30 \mathrm{~cm}$.

\section{Figure 15 \\ Exemple d'analyse de sensitivité pour un critère de sélection passage de la truite fario sur la partie amont de la passe de Kolbermoor sous des conditions de débit moyen - zone rouge : $H_{s, \min }=$ $40 \mathrm{~cm}$; zone bleue : $H_{s, \min }=30 \mathrm{~cm}$.}

to measuring maximum velocity below a slot is representative of the range of circumstances that fish encounter while arriving at an opening by attraction of the jet flow.

It is always difficult to reach an agreement of "standard" criteria for each fish species. Although we adopted criteria to assess the performance of NLFs from German experience, Figure 15 shows an example how these criteria can dramatically affect the result of performance assessment of a NLF. Continuous free passage for brown trout is plotted in the figure if flow at a slot fulfills all the requirements of maximum flow velocity nearby $\left(V_{s}\right)$, width $\left(B_{s}\right)$ and water depth $\left(H_{s}\right)$ for that species. The red zone is the result if $H_{s} \geq 40 \mathrm{~cm}$ (the threshold we adopted in this study) is respected; whereas the blue zone represents the migration corridor if $H_{s} \geq 30 \mathrm{~cm}$ is selected. By reducing the limit of $H_{s}$ from $40 \mathrm{~cm}$ to $30 \mathrm{~cm}$, the effectiveness of this ramp changes from "not passable" to "passable with multiple migration routes" for the whole ramp. This helps us to reconsider the suitability of those settled criteria, and also provides a method to define suitable criteria well, if combining it with appropriate biological investigations can be achieved.

\section{CONCLUSIONS}

The verification of hydraulics and geometry in pool-type nature-like fish migration facilities was reported via detailed experimental and field investigation. The results give us confidence that such fish migration facilities can ensure adequate conditions for multiple fish species presented in the river reach to move. This encourages wider applications and further studies on NLFs.

The streamwise velocity and flow field in the horizontal and vertical planes helped us to understand flow in NLFs. The streamwise velocity provided evidence that the maximum velocity near slots ranged from $0.8-1.0 V_{t m}$ and did not exceed $V_{t m}$. The vertical recirculations rotated counterclockwise and moved downstream when discharge increased. At high discharge, recirculations were likely either to vanish or change their rotation to clockwise. Distribution of turbulent kinetic energy showed that high TKE appeared at the right downstream side of boulder sills, instead of along the water jet, which was usually found in technical pool-type fishways.

Based on our method for field investigation, the measured velocity approached the maximum value at slots, with the higher limits approximating $0.99-1.16 \mathrm{~V}_{\mathrm{tm}}$. The performance of NLFs in fish passage relies on water depth during low flow and the arrangement of boulders. Our field investigations show that most of the qualified slots were gaps between boulders, instead of opening above arranged flat boulders. Therefore, multiple openings should be ensured, 
instead of constructing one large opening by implanting flat boulders. Attention must also be paid to maintenance of NLFs, in particular to valid openings and structure stability when floods or debris arrive.

The result of velocity measured at the two depths for $Q_{30}$ answers the question of how many points at various depths are sufficient for conducting maximum velocity measurement around a slot. It is adequate to measure at one depth if an appropriate position at the contraction of the jet flow below a slot is chosen.

The sensitivity study of various geometric/hydraulic criteria on NLFs shows that the potential migration route on nature-like ramps can be dramatically different by selecting different criteria. Thus, further study on biological monitoring, e.g. direct observation, telemetry study, etc., together with hydraulic/geometric investigations in situ should be conducted to identify appropriate criteria on assessment of fish free passage at NLFs.

\section{NOTATION}

The following symbols are used in this paper:

$B=$ width of pools;

$B_{S} \quad=$ measured width at a slot;

$B_{s, \min }=$ required minimum slot width;

$g \quad$ = gravitational acceleration;

h = water depth;

$H_{s} \quad=$ measured water depth at a slot;

$H_{s, \min } \quad=$ required minimum water depth;

$L \quad=$ length of pools;

$M Q \quad=$ annual mean flow;

$q_{p} \quad=$ specific discharge in prototype scale;

$Q_{m} \quad=$ discharge in model scale;

$Q_{30} \quad=30$-days-nonexceedence-discharge;

$Q_{330}=$ 330-days-nonexceedence-discharge;

$S=$ slope of the flume bottom;

TKE = turbulent kinetic energy;

$T K E^{*} \quad=$ normalized turbulent kinetic energy $=T K E^{1 / 2} / V_{t m}$;

$u, v, w \quad=$ velocity components in $x, y$ and $z$ directions;

$u^{*} \quad=$ normalized velocity component in $x$ direction $=u / V_{t m}$;

$u^{\prime}, v^{\prime}, w^{\prime} \quad=$ fluctuating velocity components in $x, y$ and $z$ directions;

$V_{s} \quad=$ measured maximum velocity at a slot;

$V_{t m} \quad=$ theoretical maximum velocity created by $\Delta h$ in pool-type fishways;

$V_{x y}, V_{x z} \quad=$ plane velocity in $X Y$ and $X Z$ planes;

$V_{x y}^{*}, V_{x z}^{*} \quad=$ plane velocity in $X Y$ and $X Z$ planes;

$Z^{*} \quad=$ relative depth $=Z / h$;

$\Delta h \quad=$ difference in water levels between two adjacent pools. 


\section{REFERENCES}

Dumont U., 2006. Hydraulic and geometrical requirements of fish passes, Proc. International DWA Symposium on Water Resources Management, Berlin, 31-41.

DVWK, 1996. Fischaufstiegsanlagen - Bemessung, Gestaltung, Funktionskontrolle, Merkblatt 232.

DWA, 2006. Funktionskontrolle von Fischaufstiegsanlagen [Monitoring of effectiveness of fish upstream migration facilities], DWA-Themen, p. 35, 41, 42, 45, 112-118.

FAO and DVWK, 2002. Fish Passes - Design, Dimensions and Monitoring (English version of DVWK, 1996).

Gebler R.-J., 1991. Naturgemäße Bauweisen von Sohlenbauwerken und Fischaufstiegen zur Vernetzung der Fließgewässer [Natural constructions of bottom protection structures and fish passes cross linking running waters]. Doctoral dissertation, Universität Karlsruhe, Heft 181/1991.

Goring D.G. and Nikora V.I., 2002. Despiking acoustic Doppler velocimeter data. J. Hydr. Engrg., 128, 117-126.

Görlach J., 2006. Evaluation of fish pass effectiveness, Proc. International DWA Symposium on Water Resources Management, Berlin, 130.

Heimerl S., Homilius S., Standfuß M. and Wurster H., 2005. Auslegung von Fischaufstiegsanlagen in Störsteinbauweise [Design of Upstream Migration Fishways with Perturbation Boulders]. Wasserwirtschaft, 95, 28-34.

Heimerl S., Krueger F. and Wurster H., 2008. Dimensioning of fish passage structures with perturbation boulders. Hydrobiologia, 609, 197-204.

Katopodis C., Kells J.A. and Acharya M., 2001. Nature-like and conventional fishways: alternative concepts? Canadian Water Resources J., 26, 211-232.

Larinier M., Travade F. and Porcher J.P., 2002. Fishways: biological basis, design criteria and monitoring. Bull. Fr. Pêche Piscic., 364 suppl., 208 p.

Larinier M., Courret D. and Gomes P., 2006. Guide Technique pour la Conception des Passes « Naturelles » [Technical Guide to the Concept on Nature-Like Fishways]. Rapport GHAAPPE RA.06.05-V1, 5.

Liu M., Rajaratnam N. and Zhu D.Z., 2006. Mean flow and turbulence structure in vertical slot fishways. J. Hydr. Engrg., 132, 765-777.

MUNLV, 2005. Handbuch Querbauwerke [Handbook of weirs and dams], Ministerium für Umwelt und Naturschutz, Landwirtschaft und Verbraucherschutz des Landes Nordrhein-Westfalen, p. 112, 129.

Nikora V.I., Aberle J., Biggs B.J.F., Jowett I.G. and Sykes J.R.E., 2003. Effects of fish size, time-to-fatigue and turbulence on swimming performance: a case study of Galaxias maculates. J. Fish Biol., 63, 1365-1382.

Puertas J., Pena L. and Teijeiro T., 2004. Experimental approach to the hydraulics of vertical slot fishways. J. Hydr. Engrg., 130, 10-23.

Schmutz S., Giefing C. and Wiesner C., 1998. The efficiency of a nature-like bypass channel for PikePerch (Stizostedion lucioperca) in the Marchfeldkanalsystem. Hydrobiolagica, 371/372, 355-360.

Schwevers U., 2006. General requirements of fish passes, Proc. International DWA Symposium on Water Resources Management, Berlin, 24-30.

Stephan U., Schotzko N., Haunschmid N., Petz-Glechner R. and Ullmann M., 2007. Development of a fish migration ramp - Field and laboratory experiments, Proceedings of the 6th International Symposium on Ecohydraulics, Christchurch, New Zealand, 19-23 February 2007.

Tarrade L., Texier A., David L. and Larinier M., 2008. Topologies and measurements of turbulent flow in vertical slot fishways. Hydrobiologia, 609, 177-188.

Wahl T.L., 2003. Discussion of "Despiking acoustic Doppler velocimeter data". J. Hydr. Engrg., 129, 484-488.

Wang R.W., 2008. Aspects of design and monitoring of nature-like fish passes and bottom ramps, Lehrstuhl für Wasserbau und Wasserwirtschaft, Technische Universität München.

Wang R.W., David L. and Larinier M., 2010. Contribution of experimental fluid mechanics to the design of vertical slot fish passes. Knowl. Managt. Aquatic Ecosyst., 396, 02. 